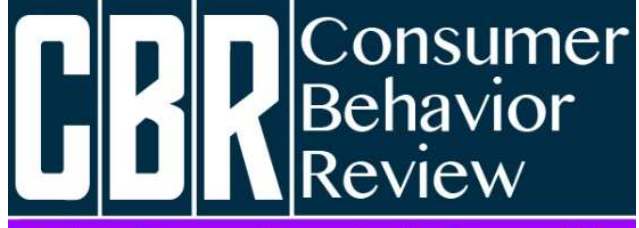

Revista Comportamento do Consumidor
Lima, E. B., Costa, C. S. R., \& Félix, G. R. (2019). Guilt and Pride Emotions and their Influence on the Intention of Purchasing Green Products. Consumer Behavior Review, 3(2), 70-84.
ISSN: 2526-7884

Editor: Prof. Dr. Marconi Freitas da Costa

Journal's e-mail: cbr@ufpe.br
Evaluation: Double blind review

Received: March 5, 2019

Accepted: September 28, 2019

\title{
GUILT AND PRIDE EMOTIONS AND THEIR INFLUENCE ON THE INTENTION OF PURCHASING GREEN PRODUCTS
}

\author{
Elton Beserra de Lima \\ Cristiane Salomé Ribeiro Costa \\ Georgia Rocha Félix
}

Elton Beserra de Lima has a degree in Business Administration from the Federal University of Pernambuco - UFPE. Email: lima.elton11@gmail.com.

Cristiane Salomé Ribeiro Costa is Professor of the Graduate Program in Management, Innovation and Consumption - PPGIC at Federal University of Pernambuco - UFPE, Campus Caruaru.

Email: csrcosta@yahoo.com.br. Georgia Rocha Félix has a degree in Business Administration from the Federal University of Pernambuco - UFPE. Email: georgiarochafelix@gmail.com. The authors thank the reviewers for their comments on improving the article.

\begin{abstract}
The aim of this paper was to analyze the influence of feelings of guilt and pride in the intention of buying green products by consumers considered sustainable. Guilt and pride are two constructs that shapes people's actions to avoid guilt-making behaviors and keep those proud, making it important to assess how these two constructs act when it comes to sustainability-related actions, in this case for green products. For this purpose, a descriptive quantitative research was used, with the survey of data performed through a survey and analyzed through multivariate statistics through the SPSS. The results showed that the emotion of guilt was identified as a stimulus factor for the purchase of green products, as a variable that would prevent the consumer to develop unsustainable behaviors, and the feeling of pride was not identified in the respondents, when researching the influence that exerts in the intention of consumers to buy green products. The result contributes to researches in sustainability field by corroborating and at the same time contrasting with research considered incipient that relate emotions to sustainable consumer behavior, opening opportunities for further research on the influence of emotions in consumers behavior in sustainability area.

Keywords: Consumer behavior, Green products, Guilt and Pride, Purchase intention, Sustainability.
\end{abstract}




\section{INTRODUCTION}

Consumption growth, especially due to population increase, has had negative consequences for the environment, such as the increase in the use of natural resources and the production's waste. Authors such as Kuwer and Fonseca (2012) and organizations such as The United Nations (UN, 2018) argue for changes in consumption patterns as an important element in achieving sustainable development.

On the other hand, there is a growing number of individuals who have been favorable to sustainability, having more positive attitudes towards social and environmental issues (Cortez \& Ortigoza, 2009) and seeking to express their position through the purchase of green products. Green products are considered as products that have in their production chain ways of preserving natural resources, such as water reuse, clean energy use, product redesign to reduce material use and disposal (Lopes \& Pacgnan, 2014).

Part of the change in consumer behavior has been related to information provided by the media, showing the negative consequences for the environment caused by consumption, providing greater knowledge about consumers actions and what they can do for the environment (Vicente -Molina, Fernández-Sáinz \& Izagirre-Olaizola, 2013). However, following Dolan's (2014) arguments, it cannot be pointed out that consumers who are aware of the problems caused by consumption behaviors are seeking to change their consumption patterns.

According to Pettie and Collins (2009), there is a gap between what individuals say they do for the environment and what they actually do, and part of that gap is connected with the complexity that surrounds the individual and their buying actions. In consumer behavior studies, it is seen that consumers respond to external influencing variables that related to internal factors can shape their buying intentions. Among the variables, the ones that receive the most attention are linked to the rational, or cognitive, and emotional, or hedonic aspect (Schinaider, Fagundes \& Schinaider, 2016).

Peloza, White and Shang (2013) understand that as they are related to actions that consumers develop without having to rationally interpret external stimuli, understanding hedonic aspects becomes more important to set behavioral patterns of individuals linked to sustainability. According to these authors, emotional responses to external stimuli makes the decision-making process automatic, because they are perceived by the consumer as self-conscious emotions, which could help to increase their actions towards sustainability.

Antonetti and Maklan (2014) point out that the dimensions of the emotional response that can play this role are guilt and pride. Wang and $\mathrm{Wu}$ (2016) state that individuals who have changed their lifestyle and are consciously consuming usually feels proud, believing that their attitudes can change the world. At the same time, those who at some point tend to make a purchase to satisfy themselves without regard to social and environmental aspects, may feel guilty and avoid consuming in similar situations of future purchases. In this sense, both emotions would act positively for sustainable behavior of individuals (Antonetti \& Maklan, 2014), something that was not researched under the purchase of green products.

Thus, understanding how the guilt and pride variables influence consumers to behave sustainably can make important contributions when understanding the relationship between purchasing behavior and sustainability. Thus, the research question that guided the development of this work was: How can sustainable consumers' guilt and pride emotions influence their intention to buy green products?

\section{THEORETICAL FRAMEWORK Purchase Intent}

Purchase intention is closely linked to how the consumer reacts at the time of a purchase, being influenced by different variables such as prices, psychological aspects and physical aspects (Vicente-Molina et al., 2013). The study by Enoki, Nami, Ferreira, Aureliano and Valdevino (2008), for example, have shown how these influences can report intentions and how individuals decide and consume certain products and services.

Purchase intent is not directly related to the product or service itself, but is linked to aspects that underlie thoughts and actions about the attitude in a specific purchase situation and in 
intent is directly linked to the cognitive and hedonic aspects through which individuals are experiencing, or feeling, at the moment that the necessity for a purchase decision occurs (Keller, 2012)

According to Silva (2017), the purchase intention is linked to the consumer's action, when they choose the type of product that will be consumed, reflecting their interests, tastes and confidence of the purchase, and thus may repeat the experience again. But it is important to point out that the intention to buy and the behavior itself are different, since the intention, the act of buying has not yet been done, and the behavior, the buying action has already been performed. In the purchase intention, the consumers may change their mind to consume a particular product, noting that their thoughts are constantly changing, but when it is made, only experience will determine the ideal judgment for that purchase.

Given these statements, it is essential to understand the attitudes behind the intention to purchase, influencing the individual's mode of consumption and reflecting on organizations that seek to understand consumer relations. In the context of sustainable consumption behavior, this perspective has been related by authors such as Pettie and Collins (2009) and Brochado, Teiga and Oliveira-Brochado (2017) as an important predictor of individuals' consumption intentions and has gained relevance with over the years and with access to information about the environment. Thus, this study understands that the fact that consumers are considered sustainable is a factor that generates influence on the intention to buy sustainable products, such as green products, leading to the first hypothesis of the research:

H1: Sustainable Consumers have a higher intention to buy green products.

\section{Sustainability and green products}

Although the topic of sustainability is relatively common among new studies, this subject has been studied since the 1970s, when the report entitled Our Common Future, better known as the Brudtland report, was released (Buarque, 2008), when it was presented to the world the negative effects on the environment derived from the increase of consumption and production. Since then, there are a variety of discourses and approaches involving the theme, with greater concentration on the environmental perspective, advocating the necessity for change in production and consumption actions in order to achieve sustainability (Santana, Perico \& Rebelato, 2006).

In this context, Keskin, Diehl and Molenaar (2013) highlights that the proposed actions have greater weight on the perspective of innovation of the production process to be more sustainable, seeking to use less natural resources while its production process can be optimized (Barbieri, 2014), opening up opportunities for the development of environmentally friendly products called green products. According to Pickett-Baker and Ozaki (2008), green products are those that can be developed or improved to green standards while meeting consumer expectations.

Green products have the same characteristics as common products, but tend to cause less damage to the environment, as they have in their production process elements that in some way minimize environmental impacts, such as biodegradable packaging, the use of less water resources and and the reduction of productive waste (Enoki et al, 2008). Thus, the raw materials used, the packaging and reusable products, the reevaluation of the damage that products may cause to health and the environment, the increased life cycle of the products and the technology to be reused, recycled or repairable, are some of the factors that can categorize a product as a green product.

Thus, through the observations used by Enoki et al. (2008) and Da Silva, Urdan, Merlo and Dias (2015), this study has as reference the perspective that green products strengthen the relationship between production and consumption focused on sustainability, causing a lower impact on the environment beyond the optimization of natural resources. Additionally, it is seen that consumers represent an important part of the relationship in favor of sustainability, as the way they consume, and the services and products they demand can directly impact the production of green products. It is true that they are being seen as more aware of the things that are happening around them in 
relation to the environment, but the factors that influence the process of consumption more conscious and how consumers respond to such influences still need to be deepened (Da Silva et al., 2015). This perspective will be seen in the following section.

\section{Consumer Behavior}

The way consumers perform their consumer activities and the factors that influence their choices has been of interest to marketing studies over the years (Keller, 1993; Pessoa, Kamlot \& Barbosa, 2016). Understanding consumer behavior can mean understanding what drives consumers to choose certain products and services over others and help companies better develop their plans to meet their needs.

In this regard, one of the themes that has been recurrent in marketing studies is related to consumer responses to external stimuli. Consumer responses refer to how individuals position themselves or behave in relation to promises promoted by the external environment. According to Schinaider et al. (2016), external stimuli act on the individual causing them to respond in two different ways, rationally and /or emotionally, the first being linked to cognitive form and the second to hedonic form.

Cognitive responses are related to the rational side of the consumer's decision making, which they will behave in an agile and practical manner, seeking and creating patterns in his conscious to make decisions. In consumption situations, information available in the environment will be rationally ordered, in which risks are minimized and benefits optimized. Hedonic responses, on the other hand, are the opposite, based on the irrational side of the decision process, and the responses express the most emotional aspect of the individual. The search for satisfaction, fulfillment, the pleasure of making the purchase, linked to their memories and affective memories, are some of the answers that consumers can present in situations of consumption in which the emotional is preponderant (Hirschman \& Holbrook, 1983; Kumar \& Oliver, 1997)

In the study of consumption, it is seen that, in certain situations, individuals try to experience more moments in which hedonic responses are stimulated than moments that may result in utilitarian responses (Hirschman \& Holbrook, 1983). In the field of sustainable consumer behavior, sustainability issues are perceived as rational by individuals and would also generate rational responses, which would make individuals avoid acting sustainably so as not to disrupt their hedonic response moments (Okada, 2005; Watson \& Spencer, 2007). This thought has prevailed in research on consumer behavior towards sustainability.

However, according to Watson and Spencer (2007), emotions are also responsible for consumer behavior and directly affect the way consumers define their choices. Unlike cognitive responses, hedonics tend to remain in the subconscious of individuals and become a reference for future decisions, which often occur through a faster process than rational perspective evaluation (Tracy \& Robins, 2007), which may be a fertile field of study, due to incipient research into the relationship of emotions and sustainable consumption (Wang $\& \mathrm{Wu}, 2016)$.

Thereby, Peloza et al. (2013) and Anttoneti and Marklan (2014) identified that, in the field of hedonic responses, two elements stand out when it comes to sustainable consumption, which are those related to guilt and pride, addressed in the following section.

\section{Guilt and pride emotions and sustainable consumption}

Studies on guilt and pride emotions and the effects on sustainable consumer behavior have received greater attention in the field of marketing and consumer behavior (Tracy \& Robins, 2007; Anttoneti \& Marklan, 2014). This is because the way these feelings can affect individuals' choices when considering consumer situations involving sustainability may be similar, even if they are considered opposite emotions. The concept of guilt is seen as a negative feeling, linked to negative responses to external elements, and is perceived as a direct consequence of personal action and can be composed of other types of negative feelings, such as remorse and discomfort (Gellis \& Hamud, 2011; Peloza et al., 2013). Pride is defined as a positive psychological state that 
plays a critical role in the consumer's sensation and is associated with the sense of satisfaction and well-being, and which increases their motivation to behave according to their personal standards (Tracy \& Robins, 2007; Williams \& DeSteno, 2009).

While negative feelings triggered by guilt emotion can lead consumers to move away from stimuli and avoid certain behaviors, positive feelings from pride emotion, on the other hand, tend to bring consumers closer to the same stimuli and keep the behavior that generated the feeling (Roseman, Spindel \& Jose, 1990; Tracy \& Robins, 2007). Following the perspective of Anttoneti and Marklan (2014), in their studies on ethical consumption, these authors suggest that, even though they are opposite feelings, both emotional states positively affect consumer behavior.

The negative effects of unsustainable consumption can make individuals feel guilty about behaving this way and this feeling can lead them to avoid the same action in new buying situations, and the feelings of pride for the resulting positive aspects, can lead consumers to maintain the same behavior that originated the emotion. Thus, both feelings can act positively to influence the consumer to more sustainable behavior, which leads to the two research hypotheses:

H2: Emotion guilt has a positive influence on consumer intention in buying green products.

H3: Emotion pride has a positive influence on the consumer's intention to buy green products.

\section{RESEARCH METHOD}

The study aims to analyze the influence that feelings of guilt and pride have on the intentions of buying green products, considered here as sustainable consumption behavior, having as population the consumers of Agreste region in Pernambuco state. In order to achieve this goal,

Table 1

Questionnaire sections

\begin{tabular}{l|c}
\hline Demographic data & 5 questions \\
\hline $\begin{array}{l}\text { Textual relationship of the scenario according to } \\
\text { Guilt }\end{array}$ & 3 questions \\
\hline Textual relation of the scenery according to Pride & 3 questions \\
\hline Perceived Consumer Effectiveness & 8 questions \\
\hline Buy intention & 3 questions \\
\hline
\end{tabular}

Source: prepared by the authors (2018) the research was quantitative descriptive, which, according to Malhotra (2012) is described as a research that aims to delineate the characteristics of a population, involving techniques and standards in data collection.

According to Tozoni-Reis (2009), quantitative research uses statistical tools to analyze data through the representation of a population, defining the research sample and the environment being studied, and it can be guaranteed that the research has legitimacy, consistency and validity. Thus, hypotheses and variables were used as reference for the construction of the questionnaire and for data analysis, ensuring that the questions were answered (Malhotra, 2012).

To this end, the research had two moments. The first, a bibliographic search was performed to compose the study variables and to design the data collection technique, by searching the Capes and Science Direct Periodic databases, for example (Kauark, Manhães \& Medeiros, 2010). The second moment was the field application to collect information. Data collection was performed in a single cross-section through a descriptive survey type questionnaire, and was applied to a predefined sample. The type of survey is characterized by Thomas, Nelson and Silverman (2012) as a research that seeks the direct response of people of a particular interest through their behavior, requesting information from groups to analyze the research problem studied and complete the study according to the analysis performed after data collection.

This study used information gathering through a questionnaire, using as reference the model of Antonetti and Maklan (2014), also including socio demographic issues. The questions were adapted to the Brazilian context and the respondents answered whether they agreed or disagreed with the statements using a 7 -point likert scale, and the questionnaire was divided into 5 sections as follows: 
So that emotions of guilt and/or pride could be aroused, consumers were stimulated through scenarios in which the former was addressed to the stimulation of guilt and the second to the stimulation of pride. In each scenario, respondents would encounter consumption situations and explanatory texts that represented each of the emotions and, after reading and understanding the consumption situation, respondents would be able to answer the questionnaire. The questions and details are in the following table 2 and the manipulated scenario is in the annex of this study:

Table 2

Scales used in research

\begin{tabular}{|c|c|c|}
\hline Author & Dimensions & Item \\
\hline \multirow{16}{*}{ 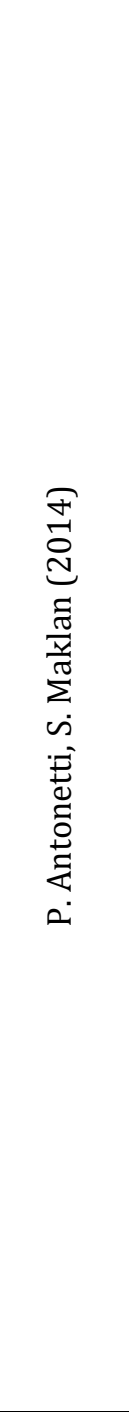 } & \multirow{3}{*}{ Guilt } & $\begin{array}{l}\text { Q1: Through the situation described, I would feel remorse not to buy green } \\
\text { product }\end{array}$ \\
\hline & & $\begin{array}{l}\text { Q2: Through the situation described, I would feel bad about not purchasing } \\
\text { green product }\end{array}$ \\
\hline & & $\begin{array}{l}\text { Q3: Through the situation described, I would feel guilty about not purchasing } \\
\text { green product }\end{array}$ \\
\hline & \multirow{3}{*}{ Pride } & $\begin{array}{l}\text { Q4: Through the situation described, I would be pleased to purchase the green } \\
\text { product }\end{array}$ \\
\hline & & $\begin{array}{l}\text { Q5: Through the situation described, I would feel good about purchasing the } \\
\text { green product }\end{array}$ \\
\hline & & $\begin{array}{l}\text { Q6: Through the situation described, I would be proud to purchase the green } \\
\text { product }\end{array}$ \\
\hline & \multirow{8}{*}{$\begin{array}{l}\text { Sustainable } \\
\text { Consumpton }\end{array}$} & $\begin{array}{l}\text { Q7: Through my personal choices, I can contribute to solving environmental } \\
\text { issues. }\end{array}$ \\
\hline & & $\begin{array}{l}\text { Q8: My personal actions are too insignificant to affect environmental issues } \\
\text { [reverse scored] }\end{array}$ \\
\hline & & Q9: Environmental issues are affected by my individual choices. \\
\hline & & $\begin{array}{l}\text { Q10: Ecological degradation is partly a consequence of my own consumption } \\
\text { choices }\end{array}$ \\
\hline & & $\begin{array}{l}\text { Q11 My individual consumption choices can contribute to promoting a more } \\
\text { environmentally friendly production process }\end{array}$ \\
\hline & & $\begin{array}{l}\text { Q12: My personal actions can influence companies' decision to adopt } \\
\text { environmental improvements in the production process }\end{array}$ \\
\hline & & $\begin{array}{l}\text { Q13: Inadequate working conditions (overuse of renewable and non- } \\
\text { renewable natural resources) are partly a consequence of my own } \\
\text { consumption choices. }\end{array}$ \\
\hline & & $\begin{array}{l}\text { Q14: My personal choices would not be able to influence a company to change } \\
\text { its entire production process for sustainability (reverse scored) }\end{array}$ \\
\hline & \multirow{2}{*}{$\begin{array}{l}\text { Buying } \\
\text { Intention }\end{array}$} & $\begin{array}{l}\text { Q15: Next time you make a purchase, I am likely to strive to buy products and } \\
\text { services from companies that develop products in sustainable production } \\
\text { processes. }\end{array}$ \\
\hline & & $\begin{array}{l}\text { Q16: Next time you make a purchase, you are likely to avoid buying products } \\
\text { and services from companies that do not develop products in sustainable } \\
\text { production processes }\end{array}$ \\
\hline
\end{tabular}

Source: prepared by the authors (2018)

A pretest was conducted to identify potential misinterpretations, especially caused by the translation of the original questionnaire, and to assess whether stimuli were perceived in the scenarios manipulated by those responding. A total of 15 questionnaires were answered. Comments were made, giving positive feedback on the questionnaire, stating that the scenario and questions were clear and easy to understand. The population of this study was composed by consumers over 18 years old from Agreste region in Pernambuco's state, because it is an industrial development pole that has been growing more and more often, with frequent 
sustainable problems. After this evaluation, the number of people to be researched through studies in the marketing area was defined, using studies by Ferraz, Romero, Rebouças and Costa (2016) and by Antonetti and Maklan (2014), involving Guilt, Pride and Sustainable Consumption. The sampling was nonprobabilistic, by judgment, using the questionnaire for the application in that particular sample, having a convenience in the population members, being selected based on the researcher's judgment (Malhotra, 2012). Thus, there was a minimum of 135 questionnaires that should be answered. This number is adequate because, according to Hair Jr., Black, Babin, Anderson and Tatham (2009), for the study using multivariate analyzes, at least a minimum of 50 respondents must be included, showing that the number for the survey is within the proposed sample.

The means used to apply the questionnaire was through the Google Docs platform, so that it could have an easy reach throughout the study territory, focusing only on the consumer audience of Agreste region in Pernambuco's state. The link went live for 20 days to enable sharing. The survey was collected between November 2nd and 21st, with the return of 145 interviews answered, being valid 138.

Data were analyzed using descriptive statistics, mean, median, mode and standard deviation to evaluate the distribution of responses and to evaluate the profile of respondents, and multivariate. The correlation test was used to evaluate the hypotheses. considering $\mathrm{p}<0.01$. For data analysis and reliability, the cronbach's alpha was used (Malhotra, 2016). All data were analyzed using the statistical data software: Statistical Package for Social Sciences (SPSS). The following section presents the analyzed data.

\section{RESULTS ANALYSIS}

To measure the demographic profile of respondents, data were collected regarding the following variables: gender, age, education level and monthly family income. Regarding gender, female respondents were represented by $57.2 \%$ while males were represented by $42.8 \%$. The most representative age of the sample was between 18 and 25 years old $(67.4 \%$ of the cases), with the option 26 to 35 years being the second most pointed by the respondents (24.6\%), which characterizes a sample of young and old. young adults (the other data: $4.3 \%$ are between 36 and 45 years old and $3.6 \%$ between 46 and 60 years old).

The educational level of the respondents is considered high, since $63.8 \%$ are in higher education and $23.2 \%$ already had completed higher education (other data: $0.7 \%$ having completed elementary school, $0.7 \%$ with o Incomplete Elementary School, 5.8\% with High School, 1.4\% with Incomplete High School, and $4.3 \%$ with another type of education (Degree and study). The answers on family income were mostly concentrated in those receiving up to $\mathrm{R} \$$ $2,862.00(63.1 \%)$, reflecting the per capita income of the region in which the survey was applied (other data: 13.8\% show an income between $\mathrm{R} \$ 2,862.01$ and $\mathrm{R} \$ 3,816.00 ; 10.9 \%$ earn between $\mathrm{R} \$ 3,816.01$ and $\mathrm{R} \$ 4,770.00$ and; $12.3 \%$ have an income greater than $\mathrm{R} \$$ 4,770.01)

After analyzing the sample profile, we followed with the analysis regarding the variables identified in this study, guilt, pride and sustainable consumption of green products. Table 3 below presents the data regarding the issues related to the emotional guilt variable.

Table 3

Data Analysis - Guilt Emotion

\begin{tabular}{l|c|c|c|c}
\multicolumn{1}{c|}{ Items } & N & Sum & Average & $\begin{array}{c}\text { Standard } \\
\text { Deviation }\end{array}$ \\
\hline $\begin{array}{l}\text { Q1: Through the situation described, would you } \\
\text { feel remorse not to buy green product }\end{array}$ & 138 & 726 & 5,26 & 1,904 \\
\hline $\begin{array}{l}\text { Q2: Through the situation described, would you } \\
\text { feel bad about not purchasing green product }\end{array}$ & 138 & 712 & 5,16 & 1,849 \\
\hline $\begin{array}{l}\text { Q3: Through the situation described, would you } \\
\text { feel guilty about not purchasing green product }\end{array}$ & 138 & 675 & 4,89 & 2,006 \\
\hline
\end{tabular}

Source: prepared by the authors (2018) 
It is possible to identify that, considering a variation from 1 strongly disagree to 7 strongly agree, it can be deduced that the respondents would feel an emotion closer to remorse and discomfort in making purchases that are not related to green products, being the related question. Specifically, the closest fault to the neutrality of feeling. Overall, respondents would feel some kind of negative emotion that they would not behave sustainably if they did not opt for the green product.

Table 4

Data Analysis - Pride Emotion

\begin{tabular}{l|c|c|c|c}
\multicolumn{1}{c|}{ Items } & N & Sum & Average & $\begin{array}{c}\text { Standard } \\
\text { Deviation }\end{array}$ \\
\hline $\begin{array}{l}\text { Q4: Through the situation described, would you be } \\
\text { pleased to purchase the green product }\end{array}$ & 138 & 782 & 5,67 & 1,702 \\
\hline $\begin{array}{l}\text { Q5: Through the situation described, would you feel } \\
\text { good about purchasing the green product? }\end{array}$ & 138 & 789 & 5,72 & 1,828 \\
\hline $\begin{array}{l}\text { Q6: Through the situation described, would you be } \\
\text { proud to purchase the green product? }\end{array}$ & 138 & 754 & 5,46 & 2,033 \\
\hline $\begin{array}{l}\text { Source: prepared by the authors (2018) }\end{array}$
\end{tabular}

In table 4 , it is possible to identify that, when it comes to the pride variable, the respondents present, on average, numbers a little closer to the totally agree option than the answers about guilt. This means that feeling proud is a little more prevalent when it comes to consuming green products than feeling guilty.

Table 5

Sustainable Consumption

\begin{tabular}{l|c|c|c|c}
\multicolumn{1}{c|}{ Items } & N & Sum & Average & $\begin{array}{c}\text { Standard } \\
\text { Deviation }\end{array}$ \\
\hline $\begin{array}{l}\text { Q7: Through my personal choices, I can contribute to } \\
\text { solving environmental issues. }\end{array}$ & 138 & 786 & 5,70 & 1,443 \\
\hline $\begin{array}{l}\text { Q8: My personal actions are too insignificant to affect } \\
\text { environmental issues (reversal scored). }\end{array}$ & 138 & 418 & 3,03 & 2,110 \\
\hline $\begin{array}{l}\text { Q9: Environmental issues are affected by my individual } \\
\text { choices. }\end{array}$ & 138 & 762 & 5,52 & 1,727 \\
\hline $\begin{array}{l}\text { Q10: Ecological degradation is partly a consequence of my } \\
\text { own consumption choices }\end{array}$ & 138 & 776 & 5,62 & 1,544 \\
\hline $\begin{array}{l}\text { Q11: Can my individual consumption choices contribute to } \\
\text { promoting a more environmentally friendly production } \\
\text { process? }\end{array}$ & 138 & 817 & 5,92 & 1,415 \\
\hline $\begin{array}{l}\text { Q12: My personal actions can influence companies' decision } \\
\text { to adopt environmental improvements in the production } \\
\text { process. }\end{array}$ & 138 & 697 & 5,05 & 1,826 \\
\hline $\begin{array}{l}\text { 13: Inadequate working conditions (overuse of renewable } \\
\text { and non-renewable natural resources) are partly a } \\
\text { consequence of my own consumption choices. }\end{array}$ & 138 & 643 & 4,66 & 1,838 \\
\hline $\begin{array}{l}\text { Q14: My personal choices would not be able to influence a } \\
\text { company to change its entire production process for } \\
\text { sustainability (reversal scored) }\end{array}$ & 138 & 519 & 3,76 & 1,969 \\
\hline
\end{tabular}

Source: prepared by the authors (2018)

In table 5 , it is possible to identify that the respondents mostly have an inclination to agree on the arguments that sustainable consumption plays an important role in environmental issues and that consumption is an important driver of change. from production processes in 
companies to cleaner processes, which reduces the negative impact on the environment. In this regard, we highlight the questions Q11, Q7 and
Q10, which reflect the closest position of respondents' sustainable consumption.

Table 6

Buying Intention

\begin{tabular}{l|c|c|c|c}
\multicolumn{1}{c|}{ Items } & N & Sum & Average & $\begin{array}{c}\text { Standard } \\
\text { Deviation }\end{array}$ \\
\hline $\begin{array}{l}\text { Q15: Next time you make a purchase, I am likely to strive to } \\
\text { buy products and services from companies that develop } \\
\text { products in sustainable production processes. }\end{array}$ & 138 & 752 & 5,45 & 1,566 \\
\hline $\begin{array}{l}\text { Q16: Next time you make a purchase, you are likely to avoid } \\
\text { buying products and services from companies that cause } \\
\text { environmental problems. }\end{array}$ & 138 & 738 & 5,35 & 1,947 \\
\hline
\end{tabular}

Source: prepared by the authors (2018)

In table 6, it was also possible to assess that respondents said, on average, that they agreed that, in their purchase intentions, they considered the possibility of making a more sustainable purchase, avoiding buying from companies that caused environmental problems and the possibility of effort to buy from those that develop sustainability actions.

The next step in data analysis was to evaluate sample reliability, calculated from Cronbach's alpha reliability coefficient, with levels considered acceptable from 0.7 (Hair Jr. et al., 2009). The total alpha value for all construct scales was 0.824 , and the separate scales have the following alphas: the guilt scale, 0.824 ; pride scale of 0.956 ; that of sustainable consumption of 0.676 , and; the purchase intention of 0.776 . Although the alpha of all variables was above the acceptable lower limit, as the values of the sustainable consumption question block variables were below 0.7 in this study, it was necessary to exclude variables in an attempt to increase the alpha value specifically. of this construct. In this process, the questions "Through my personal choices, I can contribute to solving environmental issues", "My personal actions are too insignificant to affect environmental issues" and "My personal choices would not be able to influence a company to change. entire production process for sustainability (reversal scored)", with the construct alpha after the exclusions showing a value of 0.835, generating a final alpha (considering all categories) of 0.853 .

After evaluating the reliability of the constructs, the procedure for factor analysis was performed. The KMO index of adequacy of the sample was 0.797 and the Bartlett sphericity test with significance of 0.000 (approximate chisquare of 3595.458 and 55 degrees of freedom) show that the data are adequate for factor analysis. According to table 7, the variables carried on three distinct components, each representing the block of questions related to the constructs of this research, generating three independent variables that were called 'guilt for sustainable non-consumption (GuiltNC2)', 'Pride of consumption (PrideC) 'and' Conscientious Consumer (ConsSust)'.

Table 7

Factorial Analysis

\begin{tabular}{|c|c|c|c|}
\hline \multirow{2}{*}{ Rotating component matrix ${ }^{a}$} & \multicolumn{3}{|c|}{ Components } \\
\hline & 1 & 2 & 3 \\
\hline Guilty_remorse_notbuyingsustainable & 0,195 & 0,097 & 0,920 \\
\hline Guilty_bad feeling_notbuyingsustainable & 0,256 & 0,114 & 0,881 \\
\hline Guilty_Guilty_notbuyingsustainable & 0,295 & 0,116 & 0,852 \\
\hline Pride_Satisfaction_buyingsustainable & 0,065 & 0,952 & 0,111 \\
\hline Pride_Wellbeing_buyingsustainable & 0,022 & 0,970 & 0,092 \\
\hline Pride_Prid_buyingsustainable & 0,086 & 0,938 & 0,107 \\
\hline
\end{tabular}




\begin{tabular}{|c|c|c|c|}
\hline SustainableCons.3_Environmental issues affected by individual choices & 0,753 & 0,043 & 0,146 \\
\hline SustainableCons.4_Ecological degradation resulting from consumption choices & 0,850 & 0,126 & 0,132 \\
\hline $\begin{array}{l}\text { SustainableCons.5_Personal choices influencing a good prod. goods for the } \\
\text { environment }\end{array}$ & 0,727 & 0,147 & 0,339 \\
\hline SustainableCons.6_Personal choices influencing production process & 0,723 & $-0,087$ & 0,157 \\
\hline $\begin{array}{l}\text { ustainableCons.7_W } \\
\text { hoices }\end{array}$ & 0,739 & 0,051 & 0,196 \\
\hline
\end{tabular}

Extraction Method: Principal Component Analysis.

Rotation Method: Varimax with Kaiser normaization.

a. Converged Rotation in 5 interations.

Source: prepared by the authors (2018)

To test the research hypotheses, built from the relationships pointed out in the theoretical framework, we resorted to the precepts of multiple linear regression, considering that more than one variable may be a predictor of the intention to buy green products, being considered in these studies, three independent (blame for non-sustainable consumption (GuiltNC2), sustainable consumption pride
(PrideC) and conscientious consumer (ConsSust)).

From the backward method, it was suggested the removal of the variable 'pride of sustainable consumption' (PrideC), presented as model 2 , and the inclusion of the variables 'guilt for not sustainable consumption' (GuiltNC2) and 'conscious consumer'. (ConsSust), presented as model 1 , according to table 8:

Table 8

Inserted / Removed Variables

\begin{tabular}{c|l|l|l}
\hline Model & Inserted Variables & $\begin{array}{c}\text { Removed } \\
\text { Variables }\end{array}$ & Method \\
\hline 1 & $\begin{array}{l}\text { ConsSust, PrideC, } \\
\text { GuiltaNC2 }\end{array}$ & & Insert \\
\hline 2 & & PrideC & $\begin{array}{l}\text { Backward (criterion: } \\
\text { Probability of F to be } \\
\text { removed }>=, 100) .\end{array}$ \\
\hline
\end{tabular}

a. Dependet variable: Buying_intention

b. All requested variables entered.

Source: prepared by the authors (2018)

The ANOVA analysis resulted in a statistically significant model for both models, as shown in table 9, for model $1 \mathrm{~F}(2,134)=$
17,591 and for model $2 \mathrm{~F}(2,135)=25,666$, with both $\mathrm{p}<0.05$.

Table 9

ANOVA

\begin{tabular}{c|l|c|c|c|c|c}
\hline \multirow{2}{*}{ Model } & $\begin{array}{c}\text { Sum of } \\
\text { squares }\end{array}$ & Gl & $\begin{array}{c}\text { Middle } \\
\text { Square }\end{array}$ & F & sig \\
\hline \multirow{3}{*}{1} & Regression & 359,494 & 3 & 119,831 & 17,591 & $0,000^{\mathrm{b}}$ \\
\cline { 2 - 7 } & Residue & 912,825 & 134 & 6,812 & & \\
\cline { 2 - 8 } & Total & 1272,319 & 137 & & & \\
\hline \multirow{2}{*}{2} & Regression & 350,504 & 2 & 175,252 & 25,666 & $0,000^{\mathrm{c}}$ \\
\cline { 2 - 8 } & Residue & 921,815 & 135 & 6,828 & & \\
\cline { 2 - 8 } & Total & 1272,319 & 137 & & & \\
\hline
\end{tabular}

a. Dependent Variable: Buying_intention

b. Predictors: (Constant), ConsSust, PrideC, GuiltNC2

c. Predictors: (Constant), ConsSust, GuiltNC2

Source: prepared by the authors (2018) 
To identify which model best explains the relationship of the independent variables with data presented in the model summarization table, it is possible to verify that the square $\mathrm{R}$ of models 1 and 2 are quite similar, 0.266 and 0.265 , respectively, indicating that both models the dependent variable, we observed the values of $\mathrm{R}$ square and Beta values. Considering the can explain the relationship between the constructs on the dependent variable, with model 1 better explaining the data $(\mathrm{p}<0.05)$, as shown in table 10.

Table 10

Model Summary

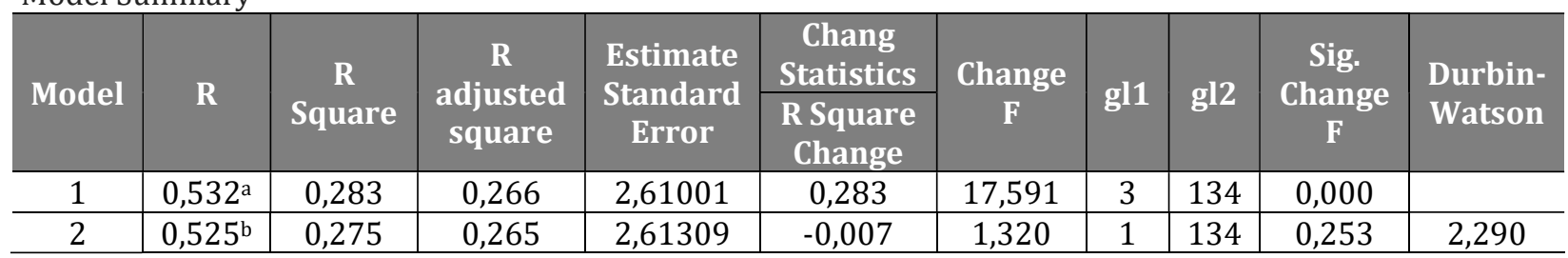
a. Predictors: (Constant), ConsSust, PrideC, GuiltNC2
b. Preditores: (Constante), ConsSust, GuiltNC2
c. Dependent Variable: Buying_intention.
Source: prepared by the authors (2018)

The beta coefficient data in Table 11 show that 'blame for non-sustainable consumption' (CulpaNC2) and 'conscious consumer' (ConsSust) (beta 0.327 and 0.278 , respectively, in model 2) are more relevant for predicting purchase intent, as beta values increased by removing the variable 'pride of sustainable consumption' (PrideC), the latter being considered not relevant to predict purchase intent (Beta $=0.087$ and $\mathrm{p}>0.05$ ), with the collinearity statistic indicating that independent variables are not highly correlated (tolerance $>0.1$ and VIF $<10$ ), which guarantees the acceptance of model 1.

Table 11

Coefficients $\underline{a}$

\begin{tabular}{|c|c|c|c|c|c|c|c|c|c|c|}
\hline & \multirow{2}{*}{ Model } & \multicolumn{2}{|c|}{$\begin{array}{l}\text { Non-standard } \\
\text { Coefficients }\end{array}$} & \multirow{2}{*}{$\begin{array}{c}\begin{array}{c}\text { Standard } \\
\text { Coefficients }\end{array} \\
\text { Beta }\end{array}$} & \multirow{2}{*}{$\mathbf{T}$} & \multirow{2}{*}{ sig } & \multicolumn{2}{|c|}{$\begin{array}{c}95.0 \% \text { confidence } \\
\text { interval for B }\end{array}$} & \multicolumn{2}{|c|}{$\begin{array}{l}\text { Collinearity } \\
\text { Statistics }\end{array}$} \\
\hline & & $\mathbf{B}$ & $\begin{array}{l}\text { Standard } \\
\text { Error }\end{array}$ & & & & $\begin{array}{l}\text { Inferior } \\
\text { Limit }\end{array}$ & $\begin{array}{l}\text { Superior } \\
\text { Limit }\end{array}$ & Tolerance & VIF \\
\hline \multirow{4}{*}{1} & (Constant) & 3,835 & 1,106 & & 3,468 & 0,001 & 1,648 & 6,022 & & \\
\hline & GuiltNC2 & 0,176 & 0,049 & 0,309 & 3,595 & 0,000 & 0,079 & 0,274 & 0,726 & 1,378 \\
\hline & PrideC & 0,049 & 0,043 & 0,087 & 1,149 & 0,253 & $-0,036$ & 0,134 & 0,943 & 1,060 \\
\hline & ConsSust & 0,128 & 0,039 & 0,275 & 3,254 & 0,001 & 0,050 & 0,206 & 0,751 & 1,331 \\
\hline \multirow{3}{*}{2} & (Constant) & 4,457 & 0,965 & & 4,618 & 0,000 & 2,548 & 6,366 & & \\
\hline & GuiltNC2 & 0,187 & 0,048 & 0,327 & 3,876 & 0,000 & 0,092 & 0,282 & 0,752 & 1,329 \\
\hline & ConsSust & 0,130 & 0,039 & 0,278 & 3,297 & 0,001 & 0,052 & 0,208 & 0,752 & 1,329 \\
\hline
\end{tabular}

a. Dependente Variable: Buyingintention

Source: prepared by the authors (2018)

With these data, it is possible to indicate that the 'blame for non-sustainable consumption' (GuiltNC2) (beta $=0.327 ; \mathrm{t}=3.876 ; \mathrm{P}<0.001$ ) and 'conscious consumer' (ConsSust) (beta = $0.278 ; \mathrm{t}=3.297 ;<0.001)$ are predictive of purchase intention.

Thus, 'H1: Consumers considered sustainable have a higher intention to buy green products' was confirmed, 'H2: Emotion guilt exerts a positive influence on consumers' intention to buy green products 'was confirmed and' H3: Emotion Pride exerts a positive influence on the consumer's intention to buy green products' was denied, as it was not considered as an important predictor ( $p>0.05)$.

Regarding the confirmation of hypothesis $\mathrm{H} 1$, consumers who consider themselves sustainable have a higher intention to buy green products, corroborates what is shown in the studies presented on the subject (Antonetti \& Maklan, 2014; Wang \& Hu, 2016). Samarasinghe (2012) points out that individuals who claim to 
be sustainable have a greater awareness of the outcome of their actions and tend to direct their consumption towards reducing the use of products that may contribute to the increase of environmental problems. Additionally, Pettie and Collins (2009) understand that individuals who already have an awareness of the potential consequences of their consumer actions on the environment prefer to buy products that are aligned with their pro-sustainability perspective. While consumers who call themselves sustainable have a greater predisposition to buy green products, Brochado et al. (2017) draw attention to the need for continued research, because even for consumers who are considered sustainable, according to these authors, or those who consider themselves sustainable, it is difficult to choose green products all the time, as other factors may influence them. so at the time of purchase.

Regarding the relationship between the feeling of guilt and the intention to buy green products, the confirmation of hypothesis $\mathrm{H} 2$ shows that the consumer feels that a potential feeling of guilt resulting from not choosing a product that is not sustainable presents itself as an important variable. Forecasting, corroborating the study by Peloza et al. (2013) and Antonetti and Maklan (2014), who said that blame is associated with a result of a rated event, perceived by the consumer as a negative emotion, and that they tend to avoid in similar shopping experiences. It is possible that these consumers have already experienced a similar sensation and this may lead to the need to avoid it (Onwezen, Antonides \& Bartels, 2013). For Nuttavuthisit and Thøgersen (2017), consumers tend to use the results of past experiences to base their future choices. And in the case of actions involving sustainability, results that have stimulated guilt may turn out to be an important predictor of new behaviors, which would explain H2's confirmation.

Regarding hypothesis H3, its nonconfirmation is in line with what was presented in the studies by Antonetti and Maklan (2014) and the studies by Wang and $\mathrm{Hu}$ (2016), in which they identified that pride is an important influencer of intention. consumers to buy ethical products in the case of the first author and sustainable products in the case of the second. According to these authors, positive feelings coupled with the pride that may result from the purchase, or which may result, should lead the consumer to engage in behaviors that could lead to similar feelings. As a positive feeling, the feeling of pride leads people to approach actions that can stimulate them (Tracy \& Robins, 2007; Penz \& Hogg, 2011). In the specific case of this study, the issue of sustainability may not be understood by consumers as a factor that promotes a sense of pride, especially in situations where sustainability is sold by the manufacturer and the consumer is not guaranteed to be true information, as may be the case involving green products. Potentially, if the consumer can perceive an immediate effect of their actions, such as participating in voluntary actions and / or working for a needy community (Tsuda, Hara \& Uwasu, 2013; Ulusoy, 2016), the feeling of Pride in doing work may be more present, but that is not the scope of work.

\section{FINAL CONSIDERATIONS}

As environmental problems become more evident, actions that can combat or reduce the causes of these problems are being demanded by society, and this also goes beyond understanding how people consume, since consumption itself is pointed as one of main causes of social and environmental problems. Different factors, including emotional factors, can influence individuals in their consumption actions and studying them enables the promotion of important information that contributes to the change in consumption behavior. Thus, the present work sought to analyze the influence that emotions guilt and pride has on the intention of sustainable consumers to buy green products.

Although emotions are not a recent topic in consumer behavior studies, research into the relationship with sustainable consumer behavior is still incipient. Thus, this study sought to generate information that could contribute to the expansion of knowledge around this relationship, presenting an already grounded theoretical perspective, emotions, with a relatively recent line of research in marketing studies, sustainable consumption behavior.

To this end, a survey was conducted with consumers from Agreste region in Pernambuco 
state, and this region was chosen because it has an important manufacturing center and because

it has been identified as a region in which consumption is growing. The results showed that the emotion of guilt influences the intention to consume green products, confirming the hypotheses of research and corroborating the perspective of other studies on this subject, such as Antonetti and Maklan (2014) and Wang and Wu. (2016). In their research, the authors investigated that this emotion influences consumer behavior because of the feelings that can cause, in the case of guilt, negative feelings that cause consumers to avoid repetition of behavior. Pride emotion was seen from the results that this variable does not influence consumers' intentions to buy green products, a result that goes against what is preached in the literature, as pride stimulates positive feelings that lead people to maintain the original behavior of this sensation. Potentially, this result can be explained why consumers may not feel a positive feeling just by buying a product that is considered green or has not yet experienced consumer situations in which this particular emotion has been stimulated.

Additionally, environmental awareness also has an important influence on the intention to consume green products, which corroborates the results of research conducted by the authors referenced in this study. For the field of sustainability, these results identified here represent an important advance in the knowledge about the intentions of individuals in relation to the most sustainable behavior. This is because there is still a gap reported in the literature that consumers can often say that they intend to consume sustainably, but in practice consumption is not realized. Observing behavior from the point of view of emotions can help to clarify this aspect by identifying which dimensions most impact consumer choices.

From this perspective, one of the points that can be deepened in relation to the results of the data analysis of this investigation is that, although both dimensions are relevant to the consumer's intentions, numbers closer to the total agreement regarding the statements were found to emotion blames, which may represent that such emotion can most strongly influence sustainable consumer behavior. Deepening why this emotion presents data that lead to the inference of being more intense than pride can be a research objective of other studies using other research methods.

Additionally, in this study it was possible to identify how the individual currently thinks about the environment, bringing consistency to new studies in the area, in which research with similar objectives and in different contexts can bring new data and information that will be important to the marketing area. Finally, it is believed that this study brings theoretical and managerial contributions, which are not exhaustive here. Theoretical because it allows identifying the relationship between emotions and sustainable consumption, and managerial because it provides important information for the communication work of green products manufactured by companies.

\section{REFERENCES}

Antonetti, P., \& Maklan, S. (2014). Feelings that make a difference: How guilt and pride convince consumers of the effectiveness of sustainable consumption choices. Journal of Business Ethics, 124(1), 117-134.

Barbieri, J. C. (2014). Desenvolvimento e meio ambiente: as estratégias de mudança da agenda 21. Petrópolis, RJ: Vozes.

Brochado, A., Teiga, N., \& Oliveira-Brochado, F. (2017). The ecological conscious consumer behaviour: Are the activists diferente? International Journal of Consumer Studies, 41.

Buarque, Sérgio C. (2008). Construindo o desenvolvimento local sustentável. Rio de Janeiro: Garamond.

Cortez, A. T. C., \& Ortigoza, S. orgs. (2009). Da produção ao consumo: Impactos socioambientais no espaço urbano. São Paulo: UNESP, 146p.

Da Silva, D.; Urdan, A., Merlo, E. M., \& Dias, K. (2015). Influências da preocupação ambiental e do ceticismo frente à propaganda no consumo de produtos verdes. Revista Brasileira de Marketing, 14(4), 529-544.

Dolan, P. (2002). The sustainability of sustainable consumption. Journal of Macromarketing, 22(2), 180-181.

Enoki, P. A., Nami, S. H., Ferreira, M. Z., Aureliano, C. A., \& Valdevino, S. L. (2008). Estratégias de Marketing Verde na Percepção de Compra dos Consumidores na Grande São Paulo. ANPAD. Curitiba, PR, p. 1-15.

Ferraz, S. B., Romero, C., Rebouças, S., \& Costa, J. (2016). Produtos verdes: um estudo sobre atitude, 
intenção e comportamento de compra de universitários brasileiros. Revista de Administração da UFSM, 9(4), 605-623.

Gellis, A. \& Hamud, M. (2011). Sentimento de culpa na obra freudiana; universal e inconsciente. Psicologia USP, 22(3), 635-653.

Hair Jr., J. F, Black, W., Babin, B., Anderson, R., \& Tatham, R. (2009). Análise multivariada de dados. 6 ${ }^{\mathrm{a}}$ ed. Porto Alegre: Bookman.

Hirschman, E. C., \& Holbrook, M. B. (1982). Hedonic consumption, emerging concepts, methods and propositions. Journal of Marketing, 46, 92101.

Tsuda, K., Hara, K., \& Uwasu, M. (2013). Prospects and challenges for disseminating life cycle thinking towards environmental conscious behaviors in daily lives. Sustainability, 5(1), 113.

Keskin, D., Diehl, J. C., \& Molenaar, N. (2013). Innovation process of new ventures driven by sustainability. Journal of Cleaner Production, 45, 50-60.

Kauark, F. S., Manhães, F. C., \& Medeiros, C. H. (2010). Metodologia da pesquisa: um guia prático. Bahia: Via Litterarum.

Keller, K. (1993). Conceptualizing, measuring, and managing customer-based brand equity. Journal of Marketing, 57(1), 1-22.

Kumar, A., \& Oliver, R. L. (1997). Special session summary cognitive appraisals, consumer emotions, and consumer response. Association for Consumer Research, 24, 17-18.

Kuwer, R. S. \& Fonseca, M. J. (2012). Perspectivas do consumo sustentável: uma análise da relação entre práticas domésticas cotidianas e sustentabilidade. Revista Acadêmica da FACE, 23(3), 244-257.

Lopes, V. N., \& Pacgnan, M. N. (2014). Marketing verde e práticas socioambientais nas indústrias do Paraná. Revista de Administração, 49(1), 166-128.

Malhotra, N. K. (2012). Pesquisa de marketing: uma orientação aplicada. Porto Alegre: Bookman, 2012.

Nuttavuthisit, K., \& Thøgersen, J. (2017). The Importance of Consumer Trust for the Emergence of a Market for Green Products: the case of organic food. Journal of Business Ethics, 140(2), 323-337.

Organizações das Nações Unidas (ONU). (2015). Transformando Nosso Mundo: A Agenda 2030 para o Desenvolvimento Sustentável. Disponível

em:

<https://nacoesunidas.org/wp-

content/uploads/2015/10/agenda2030-pt-

br.pdf > Acesso em: 18 de dez 2018.
Okada, E. M. (2005). Justification effects on consumer choice of hedonic and utilitarian goods. Journal of Marketing Research, 42(1), 43-53.

Onwezen, M., Antonides, G., \& Bartels, J. (2013). The norm activation model: An exploration of the functions of anticipated pride and guilt in proenvironmental behaviour. Journal of Economic Psychology, 39, 141-153.

Peattie, K., \& Collins, A. (2009). Guest editorial: perspectives on sustainable consumption. International Journal of Consumer Studies, 33, 107-112.

Peloza, J., White, K., \& Shang, J.Z. (2013). Good and Guilt-free: the role of self- accountability in influencing preferences for products with ethical attributes. Journal of Marketing, 77 (1), 104-119.

Pessôa, L. A. G. P., Kamlot, D., \& Barbosa, S. C. C. (2016). Compradoras compulsivas: motivações, hábitos e experiências de consumo. Revista ADM MADE, 16(1), 36-56.

Pickett-Baker J., \& Ozaki R. (2008). Proenvironmental products: marketing influence on consumer purchase decision. Journal of Consumer Marketing, 25(5), 281-93.

Roseman, I. J., Spindel, M. S., \& Jose, P. E. (1990). Appraisals of emotion-eliciting events: Testing a theory of discrete emotions. Journal of Personality and Social Psychology, 59(5), 899-915.

Santana, N., Perico, A., \& Rebelatto, D. (2006). Investimento em responsabilidade sócioambiental de empresas distribuidoras de energia elétrica: uma análise por envoltória de dados. Revista Gestão Industrial, 2(4), 124139.

Schinaider, A. D., Fagundes, P. M., \& Schinaider, A. D. (2016). Comportamento do consumidor educacional: seu perfil e o processo de decisão de compra. Future Studies Research Journal, 8(2), 144-164.

Silva, A. C. R. S. (2017). Os determinantes da intenção de compra dos consumidores através do Instagram. 188f. Dissertação de Mestrado Instituto Politécnico de Lisboa.

Thomas, J. R., Nelson, J. K., \& Silverman, S. J. (2012). Métodos de pesquisa em atividade física. $6^{\mathrm{a}} \mathrm{ed}$. Porto Alegre: Artmed.

Tozoni-Reis, M. F. C. (2009). Metodologia de pesquisa. $2^{\underline{a}}$ ed, Curitiba: IESDE Brasil S.A.

Tracy, J. L., \& Robins, R. W. (2007). The psychological structure of pride: A tale of two facets. Journal of Personality and Social Psychology, 92(3), $506-525$.

Ulusoy, E. (2016). Experiential responsible consumption. Journal of Business Research, 69(1), 284-297. 
Vicente-Molina, M. A., Fernández-Sáinz, A., \& Izagirre-Olaizola, J. (2013). Environmental

knowledge and other variables affecting proenvironmental behaviour: Comparison of university students from emerging and advanced countries. Journal of Cleaner Production, 61, 130-138.

Watson, L., \& Spencer, M. (2007). Causes and consequences of emotions on consumer behaviour: A review and integrative cognitive appraisal theory. European Journal of Marketing, 41 (5/6), 487-511.

Wang, J., \& Wu, L. (2016). The impact of emotions on the intention of sustainable consumption choices: evidence from a big city in an emerging country. Journal of Cleaner Production, 126, 325-226.

Williams, L., \& DeSteno, D. (2009). Pride: Adaptive social emotion or seventh sin? Psychological Science.

\section{ANNEX A: SCENARIO HANDLIN GUILT}

You go to your local market, and then you decide that you will choose a new brand of coffee on the spot. On the shelf, you come across two marks. You won't be able to delay buying so you have to decide between these two brands. Details of both options are below:

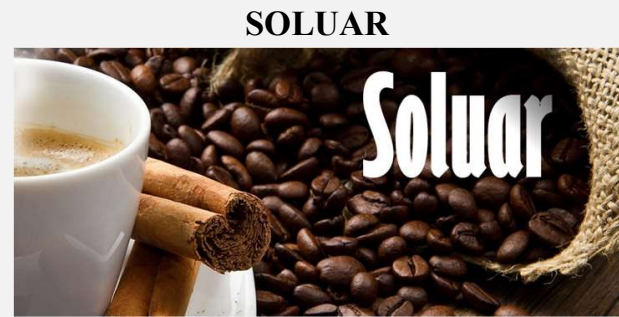

- 500g for $\mathrm{R} \$ 5,90$

- Unique taste

- Selected Grains

- Region: Minas Gerais

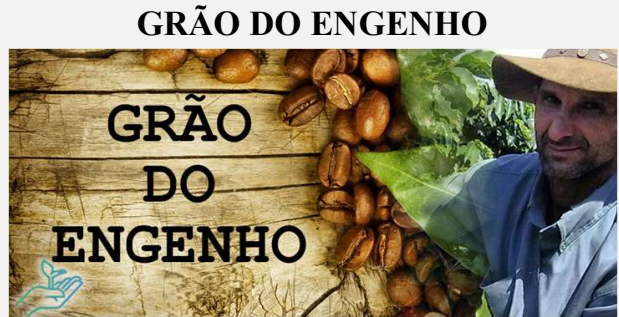

- $500 \mathrm{~g}$ for $\mathrm{R} \$ 7,10$

- Unique taste

- FARMER NGO ensures a better working condition and conservation of the planting soil.

- Region: Minas Gerais

he moment you are deciding, you remember that you saw in the Morning Newspaper that you were told about the conditions of the coffee farmers in Minhas Gerais. It was discussed how workers are exploited to sell coffee beans to large companie for a price well below the market. SOLUAR was mentioned with one of the brands that exploits these workers. The newspaper also cited how the Farmer's NGO offers good conditions for farmers and helps in adapting the environment and farming practices.

You're in a hurry and don't want to waste a lot of time choosing. You decide to save money by taking the cheapest product as there is no difference in taste. So you decide to take SOLUAR. 